\title{
Studi komparasi learning cycle $5 E$ dan learning together dikombinasi dengan drill and practice terhadap prestasi belajar kimia ditinjau dari keterampilan proses siswa
}

\author{
Mita Fujiyanti *, Endang Susilowati, Sulistyo Saputro \\ Program Studi Pendidikan Kimia, Fakultas Keguruan dan Ilmu Pendidikan, Universitas Sebelas Maret. \\ Jalan Ir. Sutami No.36A, Jebres, Kota Surakarta, Jawa Tengah 57126, Indonesia \\ * Coressponding Author. E-mail: mfujiyanti63@gmail.com \\ Received: 22 February 2018; Revised: 25 April 2018; Accepted: 23 October 2018
}

\begin{abstract}
Abstrak
Penelitian ini bertujuan untuk mengetahui perbedaan prestasi belajar antara siswa yang diberikan model pembelajaran Learning Cycle $5 E$ dan Learning Together dikombinasikan dengan Drill and Practice; siswa yang memiliki keterampilan proses tinggi dan keterampilan proses rendah; serta interaksi antara pembelajaran Learning Cycle 5E dan Learning Together dikombinasi dengan Drill and Practice dengan keterampilan proses siswa terhadap prestasi belajar siswa pada materi pokok hidrolisis garam. Penelitian ini merupakan penelitian kuantitatif dengan metode eksperimen. Sampel penelitian terdiri dari dua kelas siswa (XI MIA 1 dan XI MIA 3) yang ditentukan dengan menggunakan teknik cluster random sampling. Data diperoleh melalui tes tertulis, angket, observasi. Hasil penelitian dapat disimpulkan bahwa: (1) siswa yang diberikan penerapan model pembelajaran Learning Cycle $5 E$ memiliki prestasi belajar yang lebih baik dibandingkan siswa yang diberikan penerapan model pembelajaran Learning Together yang dikombinasikan dengan Drill and Practice; (2) siswa yang memiliki keterampilan proses tinggi memiliki prestasi belajar yang lebih baik dibandingkan siswa yang memiliki keterampilan proses rendah; dan (3) terdapat interaksi antara model pembelajaran Learning Cycle $5 E$ dan Learning Together yang dikombinasikan dengan Drill and Practice dengan keterampilan proses siswa.
\end{abstract}

Kata Kunci: learning cycle 5E, learning together, drill and practice, keterampilan proses, prestasi belajar

\section{Comparison study of learning cycle $5 E$ and learning together combined with drill and practice on student achievement in hydrolysis of salt viewed from process skills}

\begin{abstract}
The aim of this study were to know differences student's achievement between Learning Cycle $5 E$ models and Learning Together in combination with Drill and Practice; student's achievement between higher process skill and lower process skill; and interaction between Learning Cycle 5E and Learning Together in combination with Drill and Practice models with process skill towards student's achievement. This research is a quantitative research with experimental method. The sample consists of 2 class which taken by cluster random sampling technique. The techniques of collecting data using documentation, test, questionnaire, and observation. Based on result of the research can be concluded that: (1) student's achievement of chemistry learning use Learning Cycle 5E better than Learning Together in combination with Drill and Practice models; (2) student's achievement higher process skill better than lower process skill; and (3) there was an interaction between Learning Cycle 5E and Learning Together in combination with Drill and Practice models with process skill towards student's achievement.
\end{abstract}

Keywords: learning cycle 5E, learning together, drill and practice, process skill, student achievement.

How to Cite: Fujiyanti, M., Susilowati, E., \& Saputro, S. (2018). Studi komparasi learning cycle 5E dan learning together dikombinasi dengan drill and practice terhadap prestasi belajar kimia ditinjau dari keterampilan proses siswa. Jurnal Inovasi Pendidikan IPA, 4(1), 104-113. doi:http://dx.doi.org/10.21831/jipi.v4i1.18640

doi http://dx.doi.org/10.21831/jipi.v4i1.18640 


\section{PENDAHULUAN}

Pendidikan merupakan salah satu aspek yang penting dalam menentukan kemajuan bangsa untuk meningkatkan sumber daya manusia. Pendidikan masih memiliki peran yang signifikan dan bahkan masih menjadi pranata utama dalam penyiapan sumber daya manusia. Sebagaimana yang tercantum dalam Undangundang No 20 Tahun 2003 Pasal 3, Pendidikan Nasional berfungsi mengembangkan kemampuan dan membentuk watak serta peradaban bangsa yang bermartabat dalam rangka mencerdaskan kehidupan bangsa, bertujuan untuk berkembangnya potensi peserta didik agar menjadi manusia yang beriman dan bertaqwa kepada Tuhan Yang Maha Esa, berakhlak mulia, sehat, berilmu, cakap, kreatif, mandiri, dan menjadi warga negara yang demokratis serta bertanggung jawab (Presiden Republik Indonesia, 2003). Peran pendidikan yang begitu penting dalam peningkatan sumber daya manusia tersebut, menuntut adanya peningkatan kualitas pendidikan secara bertahap dan berkelanjutan. Salah satu upaya yang dapat dilakukan pemerintah khususnya Departemen Pendidikan Nasional adalah pembaharuan sistem pendidikan yang diarahkan kepada perubahan kurikulum.

Kurikulum 2013 adalah kurikulum yang berlaku saat ini. Kurikulum 2013 menekankan pada pendekatan ilmiah, yaitu pendekatan yang menekankan bahwa kegiatan pembelajaran yang berlangsung harus mengandung aspek $5 \mathrm{M}$; mengamati, menanya, mengumpulkan informasi, mengasosiasi dan mengomunikasikan. Pembelajaran berdasarkan kurikulum 2013 berpusat pada siswa, guru hanya berperan sebagai fasilitator, bukan sebagai penyampai konsep yang utama.

Berkaitan dengan karakteristik kurikulum 2013 tersebut, diperlukan adanya perubahan model pembelajaran yang diterapkan oleh guru dalam proses pembelajaran. Akan tetapi pada kenyataannya, masih banyak guru yang belum maksimal dalam menerapkan model pembelajaran yang sesuai dengan karakteristik dari Kurikulum 2013. Proses pembelajaran yang berlangsung cenderung masih berpusat pada guru. Sebagian besar waktu belajar di kelas dihabiskan untuk mendengarkan guru ceramah dan menghafalkan serta mencatat materi. Di sisi lain, pembelajaran yang berlangsung hanya berorientasi pada penuntasan penyampaian materi, tanpa memperhatikan kualitas proses pembelajaran. Akibatnya, suasana kelas menjadi monoton dan banyak siswa yang merasa bosan serta kesulitan untuk memahami materi yang diberikan oleh guru.

SMA Negeri 5 Surakarta merupakan salah satu sekolah yang sudah menerapkan kurikulum 2013. Di sekolah tersebut mata pelajaran kimia masih dianggap sulit oleh sebagian besar siswa yang mempelajarinya. Hal ini didasarkan pada hasil belajar yang dicapai oleh siswa pada Penilaian Akhir Semester (PAS) ganjil mata pelajaran kimia yang masih belum maksimal.

Salah satu materi kimia yang diberikan kepada siswa Sekolah Menengah Atas (SMA) adalah materi hidrolisis garam. Di dalam materi ini, siswa mempelajari konsep hidrolisis, jenis garam dan reaksi hidrolisis, $\mathrm{pH}$ larutan garam dan penggunaan hidrolisis dalam kehidupan. Materi ini merupakan materi yang kompleks dan menuntut kemampuan matematis untuk menerapkan konsep stoikiometri dalam menentukan banyaknya ion garam yang mengalami hidrolisis.

Sementara itu, faktor eksternal yang berpengaruh terhadap hasil belajar siswa adalah model pembelajaran yang diterapkan. Hal ini merupakan tugas dari seorang guru, sebagaimana menurut Dimyati \& Mudjiono (2002, p. 37) yang menyatakan bahwa seorang guru memiliki peranan penting dalam proses pembelajaran. Salah satu diantaranya adalah melakukan pembelajaran sesuai dengan berbagai model pembelajaran yang disesuaikan dengan kondisi siswa, bahan belajar, dan kondisi sekolah setempat serta kemampuan guru (Dimyati \& Mudjiono, 2002).

Learning Cycle $5 E$ adalah model pembelajaran dengan pendekatan konstruktivis, dimana siswa diberikan kesempatan untuk mengkonstruksi pengetahuan dan pengalaman mereka sendiri. Model pembelajaran ini terdiri dari lima tahap yaitu: (1) Engagement (pembangkitan minat), (2) Exploration (eksplorasi), (3) Explanation (penjelasan), (4) Elaboration (elaborasi), dan (5) Evaluation (evaluasi). Model pembelajaran Learning Cycle dapat meningkatkan motivasi belajar siswa, membantu mengembangkan sikap ilmiah siswa, mengaktualisasikan dan mengoptimalkan dirinya, serta dapat menerima pengalaman dan dimengerti oleh orang lain (Shoimin, 2014). Selain itu, Model pembelajaran Learning Cycle ini juga dapat mengembangkan keterampilan proses siswa, memberi kesempatan kepada siswa untuk melakukan percobaan secara langsung dan menemukan konsep secara 
mandiri. Sehingga proses pembelajaran yang berlangsung menjadi lebih bermakna.

Model pembelajaran lainnya yang patut untuk diperhatikan adalah Learning Together. Pada pelaksanaannya siswa ditempatkan dalam kelompok kecil dan diminta untuk menghasilkan satu produk kelompok. Guru bertugas untuk mengawasi kelompok berdasarkan lima elemen kooperatif: ketergantungan positif, tanggung jawab individu, interaksi langsung, keterampilan-keterampilan sosial, dan pemrosesan kelompok (Huda, 2012). Model pembelajaran ini cocok digunakan untuk semua materi pelajaran, melatih kerjasama yang baik antar-anggota kelompok, dapat mengembangkan ide atau gagasan, dan memungkinkan peran aktif setiap siswa dalam pemikiran yang kritis serta dapat meningkatkan kemampuan pemecahan masalah (Slavin, 2015).

Metode pembelajaran yang juga perlu diperhatikan adalah Drill and Practice. Metode Drill and Practice memiliki lima fase pembelajaran, yaitu: (1) mendapatkan tujuan-tujuan, (2) mendemonstrasikan pengetahuan atau skill, (3) memberikan latihan-latihan yang dibimbing, (4) mengecek pemahaman dan memberi feedback dan (5) memberikan latihan lanjut. Metode ini tepat diterapkan dalam pembelajaran materi hitungan, bahasa asing dan peningkatan perbendaharaan kata-kata (vocabulary) (McDonough, 2001).

Dalam penerapan di kelas, model pembelajaran Learning Together masih memiliki kelemahan, yaitu tanggungjawab individu rendah, membutuhkan waktu cukup lama dan tidak dapat melihat kemampuan setiap siswa (Huda, 2012). Metode Drill and Practice juga memiliki kelemahan kurang mampu mengakomodir bakat dan inisiatif siswa serta terkadang membosankan (Sagala, 2010).

Dengan memperhatikan karakteristik dari masing-masing tahapan pembelajaran pada setiap model, maka langkah-langkah pembelajaran dari gabungan model Learning Together dengan Drill and Practice adalah (1) mendapatkan tujuan; (2) mendemonstrasikan pengetahuan atau skill; (3) membuat kelompok; (4) presentasi; (5) latihan lanjut dengan masalah yang lebih komplek.

Dalam model pembelajaran Learning Cycle 5E pemahaman konsep dilakukan melalui pengalaman langsung yang bertahap dan bersiklus. Siswa mengembangkan pemahamannya terhadap suatu konsep dengan kegiatan mencoba (hands on activities), kemudian konsep yang telah dipahaminya tersebut akan diuji oleh guru dan dilanjutkan dengan pengembangan lebih lanjut secara mandiri. Sementara itu, model pembelajaran Learning Together merupakan model pembelajaran yang berlandaskan kooperatif serta Drill and Practice berlandaskan konstruktivis. Dua model pembelajaran tersebut apabila digabungkan akan menekankan pada proses pembelajaran secara berkelompok dengan latihan yang berulang. Pengulangan latihan ini akan membuat siswa memiliki kesempatan yang lebih banyak untuk memahami konsep yang sedang dipelajari. Selain itu, tujuan penggabungan model ini untuk meminimalisir kelemahan yang dimiliki oleh masing-masing model pembelajaran dan untuk mengimbangi model pembelajaran Learning Cycle $5 E$ yang berlandaskan kooperatif-konstruktivis.

Selain faktor eksternal, terdapat faktor internal yang mempengaruhi hasil belajar siswa. Masih banyak guru yang belum sepenuhnya memperhatikan faktor internal siswa, sehingga model pembelajaran yang digunakan tidak sesuai dengan kebutuhan siswa. Apabila dilihat dari karakteristik model pembelajaran yang telah diuraikan sebelumnya, serta dikaitkan dengan materi pembelajaran yang akan diberikan yaitu materi hidrolisis garam, maka faktor internal siswa yang terlihat dapat berpengaruh pada prestasi belajar siswa adalah keterampilan proses. Menurut Funk dalam Dimyati \& Mudjiono (2002, p. 140) keterampilan proses terdiri dari keterampilan dasar dan keterampilan terintegrasi (Dimyati \& Mudjiono, 2002). Keterampilan dasar meliputi mengobservasi, mengklasifikasi, memprediksi, mengukur, menyimpulkan, dan mengkomunikasikan. Sedangkan keterampilan terintegrasi terdiri dari mengidentifikasi variabel, membuat tabulasi data, menyajikan data dalam bentuk grafik, menggambarkan hubungan antar-variabel, mengumpulkan dan mengolah data, menganalisa penelitian, menyusun hipotesis, mendefinisikan variabel secara operasional, merancang penelitian, dan melaksanakan eksperimen. Keterampilan proses harus ditumbuhkan dalam diri siswa SMA sesuai dengan taraf perkembangan pemikirannya (Kuswaya \& Wardani, 2008). Keterampilan proses yang dimiliki siswa memberikan kesempatan kepada siswa untuk bertindak sebagai penemu dalam pembelajaran kimia, sehingga diharapkan dengan adanya keterampilan proses dapat mendorong adanya peningkatan dalam pemahaman serta penguasaan materi. Keterkaitan antara materi hidrolisis garam dengan keterampilan 
proses adalah dalam materi hidrolisis garam terdapat beberapa konsep yang menuntut siswa untuk menggunakan keterampilan proses yang dimilikinya. Contohnya, menentukan sifat larutan garam yang dilakukan dengan eksperimen di laboratorium. Keterampilan proses juga dapat mendukung terlaksananya model pembelajaran Learning Cycle $5 E$ dan Learning Together dikombinasi dengan Drill and Practice. Siswa yang memiliki keterampilan proses tinggi akan lebih mudah mengikuti model pembelajaran yang diterapkan dan mendapatkan hasil belajar yang baik. Sedangkan siswa yang memiliki keterampilan proses rendah diharapkan akan lebih termotivasi untuk dapat berpartisipasi secara aktif dalam pembelajaran, sehingga hasil belajar yang diperoleh dapat meningkat.

\section{METODE}

Penelitian ini menggunakan metode eksperimen dengan desain faktorial $2 \times 2$.Rancangan penelitian ini secara lebih ringkas, terdapat dalam Tabel 1.

Tabel 1. Rancangan Penelitian Kuasi Eksperimental Desain Faktorial 2x2.

\begin{tabular}{lccc}
\hline \multirow{2}{*}{ Kelas } & \multirow{2}{*}{} & \multicolumn{2}{c}{ B } \\
\cline { 3 - 4 } & & $\mathbf{B}_{\mathbf{1}}$ & $\mathbf{B}_{\mathbf{2}}$ \\
\hline Eksperimen I & $\mathrm{A}_{1}$ & $\mathrm{~A}_{1} \mathrm{~B}_{1}$ & $\mathrm{~A}_{1} \mathrm{~B}_{2}$ \\
Eksperimen II & $\mathrm{A}_{2}$ & $\mathrm{~A}_{2} \mathrm{~B}_{1}$ & $\mathrm{~A}_{2} \mathrm{~B}_{2}$ \\
\hline
\end{tabular}

Keterangan:

$\mathrm{A}_{1}$ : Pembelajaran dengan model Learning Cycle $5 E$

$\mathrm{A}_{2}$ : Pembelajaran dengan model Learning Together dan Drill and Practice

$\mathrm{B}_{1}$ : Keterampilan Proses Tinggi

$\mathrm{B}_{2}$ : Keterampilan Proses Rendah

$\mathrm{A}_{1} \mathrm{~B}_{1}$ : Pembelajaran dengan model Learning cycle $5 E$ pada siswa yang memiliki keterampilan proses tinggi

$\mathrm{A}_{1} \mathrm{~B}_{2}$ : Pembelajaran dengan model Learning cycle $5 E$ pada siswa yang memiliki keterampilan proses rendah

$\mathrm{A}_{2} \mathrm{~B}_{1}$ : Pembelajaran dengan model Learning Together dan Drill and Practice pada siswa yang memiliki keterampilan proses tinggi

$\mathrm{A}_{2} \mathrm{~B}_{2}$ : Pembelajaran dengan model Learning Together dan Drill and Practice pada siswa yang memiliki keterampilan proses rendah

Populasi dari penelitian ini adalah seluruh siswa kelas XI MIA SMA Negeri 5 Surakarta tahun ajaran 2016/2017 yang terdiri dari 5 kelas, yaitu kelas XI MIA 1, XI MIA 2, XI MIA 3, XI MIA 4 dan XI MIA 5. Pengambilan sampel menggunakan teknik Cluster Random Sampling. Dari lima kelas XI MIA SMA Negeri 5 Surakarta, diambil dua kelas secara acak untuk dijadikan kelas sampel dan diperoleh kelas XI MIA 3 sebagai kelas eksperimen I yang diberikan perlakuan model pembelajaran Learning Cycle 5E dan kelas XI MIA 1 sebagai kelas eksperimen II yang diberikan perlakuan model pembelajaran Learning Together dikombinasi Drill and Practice.

Variabel bebas dalam penelitian ini adalah model pembelajaran yang diterapkan. Variabel terikat adalah prestasi belajar pada materi hidrolisis garam dan variabel moderator adalah keterampilan proses yang digolongkan menjadi dua kategori yaitu tinggi dan rendah.

Teknik pengumpulan data yang digunakan adalah: (1) instrumen tes untuk mengukur keterampilan proses dan prestasi belajar aspek pengetahuan dengan bentuk soal objektif; (2) angket untuk mengukur prestasi belajar aspek sikap; (3) observasi untuk mengukur prestasi belajar aspek sikap, keterampilan dan keterampilan proses.

Instrumen pengambilan data meliputi instrumen penilaian pengetahuan, sikap, keterampilan dan keterampilan proses. Teknik analisis instrumen pengetahuan menggunakan: (1) Uji validitas menggunakan formula Gregory (Gregory, 2004) dinyatakan valid dengan nilai content validity 0,92 ; (2) Uji reliabilitas dinyatakan reliabel dengan harga reliabilitas 0,93; (3) Uji tingkat kesukaran soal diperoleh hasil dari 25 soal yang diujicobakan, 4 soal tergolong sukar, 10 soal tergolong sedang dan 11 soal tergolong mudah; (4) Uji daya beda soal diperoleh hasil 3 soal dinyatakan baik sekali, 15 soal berkategori baik, 5 soal cukup baik dan 2 soal berkategori jelek. Teknik analisis angket sikap menggunakan: (1) Uji validitas dengan formula Gregory dinyatakan valid dengan nilai content validity 0,94 (untuk angket penilaian diri) dan 0,83 (untuk observasi); (2) Uji reliabilitas dinyatakan reliabel dengan harga reliabilitas 0,87 . Teknik analisis instrumen keterampilan menggunakan uji validitas dengan formula Gregory dan dinyatakan valid dengan nilai content validity 1 . Sementara itu, untuk teknik analisis instrumen keterampilan proses menggunakan: (1) Uji validitas dengan formula Gregory dinyatakan valid dengan nilai content validity 0,80 (untuk tes objektif) dan 0,86 (untuk lembar observasi); (2) Uji reliabilitas dinyatakan reliabel dengan harga reliabilitas 0,81 ; (3) Uji tingkat kesukaran soal diperoleh hasil dari 20 soal yang diujicobakan, 2 soal tergolong sukar, 6 soal tergolong sedang dan 12 soal tergolong mudah; (4) Uji daya beda soal diperoleh hasil 2 soal 
dinyatakan baik sekali, 13 soal berkategori baik, 3 soal cukup baik dan 2 soal berkategori jelek.

Uji prasyarat analisis yang dilakukan adalah uji keseimbangan, uji normalitas dan uji homogenitas. Sedangkan teknik analisis data menggunakan uji analisis variansi dua jalan sel tak sama, uji Kruskal Wallis dan uji lanjut Scheffe. Uji prasyarat analisis dan uji hipotesis dalam penelitian ini dilakukan dengan menggunakan bantuan software SPSS 19.

\section{HASIL DAN PEMBAHASAN}

Data nilai UAS digunakan untuk uji normalitas, homogenitas, dan uji t-matching.Hasil uji normalitas disajikan pada Tabel 2. Berdasarkan hasil tersebut kelas yang terdistribusi normal adalah kelas XI MIA 1, XI MIA 2, XI MIA 3 dan XI MIA 4. Hasil uji homogenitas menyatakan bahwa seluruh kelas XI MIA memiliki varian yang homogen dengan taraf signifikansi lebih besar dari 0,05 , sehingga dapat dijadikan sebagai sampel penelitian. Hasil uji homogenitas secara ringkas disajikan pada Tabel 3. Adapun untuk uji $t$-matching dapat dilihat pada Tabel 4 dan dapat disimpulkan bahwa kelas yang digunakan sebagai sampel, yaitu kelas XI MIA 1 dan XI MIA 3 memiliki kemampuan setara. Hal ini ditunjukkan dengan nilai Sig. (2-tailed) sebesar 0,509 .

Tabel 2. Hasil Uji Normalitas Kemampuan Awal

\begin{tabular}{ccc}
\hline Kelas & Signifikansi & Keterangan \\
\hline XI MIA 1 & 0,925 & Normal \\
XI MIA 2 & 0,654 & Normal \\
XI MIA 3 & 0,944 & Normal \\
XI MIA 4 & 0,794 & Normal \\
XI MIA 5 & 0,008 & Tidak Normal \\
\hline
\end{tabular}

Tabel 3. Hasil Uji Homogenitas Kemampuan Awal

\begin{tabular}{ccc}
\hline & Sig. & Ket. \\
\hline Nilai UAS Kelas XI MIA & 0,487 & Homogen \\
\hline
\end{tabular}

Tabel 4. Hasil Uji t-matching

\begin{tabular}{ccc}
\hline & Sig. & Keterangan \\
\hline XI MIA 1 dan XI MIA 3 & 0,509 & Setara \\
\hline
\end{tabular}

Setelah mendapatkan data prestasi belajar siswa, selanjutnya dilakukan uji prasyarat analisis (uji normalitas dan homogenitas).Hasil uji normalitas menunjukkan bahwa data prestasi belajar siswa aspek pengetahuan dan keterampilan berdistribusi normal.Sedangkan untuk nilai prestasi belajar aspek sikap tidak berdistribusi normal. Sementara itu, hasil uji homogenitas varians menunjukkan bahwa data nilai prestasi belajar siswa untuk semua aspek memiliki variansi yang homogen, ditunjukkan dengan taraf signifikansi lebih dari 0,05.

Langkah selanjutnya adalah melakukan pengujian hipotesis penelitian. Uji hipotesis untuk data nilai aspek pengetahuan dan keterampilan dilakukan menggunakan analisis variansi (ANAVA) dua jalan dengan sel tak sama. Sedangkan untuk nilai sikap dilakukan menggunakan uji K-Independent Sample Kruskal Wallis. Masing-masing uji dilakukan pada taraf signifikansi 0,050. Hasil dari uji hipotesis untuk masing-masing aspek prestasi belajar disajikan pada Tabel 5. Sementara itu, untuk rataan nilai prestasi belajar dari kedua kelas eksperimen dan kategori keterampilan proses disajikan pada Tabel 6.

\section{Hipotesis Pertama}

Pengujian hipotesis pertama dilakukan untuk mengetahui perbedaan penerapan model pembelajaran Learning Cycle $5 E$ dan Learning Together yang dikombinasikan dengan Drill and Practice terhadap prestasi belajar siswa.

Hasil pengujian hipotesis untuk aspek pengetahuan menunjukkan bahwa signifikansi uji yang diperoleh adalah 0,039. Hasil ini menyatakan bahwa terdapat perbedaan prestasi belajar siswa pada penerapan model pembelajaran Learning Cycle 5E dan Learning Together dikombinasi dengan Drill and Practice.

Berdasarkan data pada Tabel 6 dapat diketahui bahwa besarnya rataan nilai siswa pada kelas eksperimen I memiliki nilai prestasi belajar aspek pengetahuan yang lebih tinggi dibandingkan dengan siswa pada kelas eksperimen II. Pada tahap awal kedua kelas ini telah diuji kesamaan rata-rata, dengan hasil yang menyatakan bahwa kedua kelas ini memiliki kemampuan awal yang setara, sehingga dapat disimpulkan bahwa siswa pada kelas eksperimen I yang diberi perlakuan berupa penerapan model pembelajaran Learning Cycle $5 E$ memiliki nilai prestasi belajar aspek pengetahuan yang lebih tinggi dibandingkan dengan siswa pada kelas eksperimen II yang diberikan perlakuan berupa penerapan model pembelajaran Learning together dikombinasikan dengan Drill and Practice. Model Learning Cycle 5E lebih unggul karena dalam pelaksanaannya sangat berpusat pada siswa, sehingga dapat meningkatkan motivasi siswa karena siswa dilibatkan secara aktif dalam proses pembelajaran, mampu membuat pembelajaran lebih bermakna, dan mampu 
mengembangkan sikap ilmiah serta potensi individu siswa.

Uji ANAVA pada prestasi belajar aspek keterampilan menunjukkan bahwa signifikansi yang diperoleh yaitu 0,992 . Hasil ini menunjukkan bahwa tidak terdapat perbedaan prestasi belajar antara penggunaan model pembelajaran Learning Cycle $5 E$ dan Learning Together dikombinasi dengan Drill and Practice. Besarnya rataan nilai prestasi belajar aspek pengetahuan siswa yang diberikan perlakuan berupa penerapan model pembelajaran Learning together dikombinasikan dengan Drill and Practice adalah 84,03 . Sedangkan besarnya rataan nilai prestasi belajar aspek pengetahuan siswa yang diberikan perlakuan berupa penerapan model pembelajaran Learning Cycle $5 E$ adalah 84,72. Kedua rataan tersebut tidak menunjukkan adanya pengaruh perbedaan yang signifikan antara model pembelajaran yang diterapkan terhadap prestasi belajar siswa aspek keterampilan pada materi hidrolisis garam. Pada tahap awal kedua kelas ini telah diuji kesamaan rata-rata, dengan hasil yang menyatakan bahwa kedua kelas ini memiliki kemampuan awal yang setara, sehingga dapat disimpulkan bahwa siswa pada kelas eksperimen II yang diberi perlakuan berupa penerapan model pembelajaran Learning Cycle $5 E$ memiliki nilai prestasi belajar aspek keterampilan yang lebih tinggi dibandingkan dengan siswa pada kelas eksperimen I yang diberikan perlakuan berupa penerapan model pembelajaran Learning together dikombinasikan dengan Drill and Practice. Tidak terdapatnya pengaruh dalam penerapan model pembelajaran yang digunakan terhadap prestasi belajar aspek keterampilan siswa ini dapat disebabkan oleh pengukuran aspek keterampilan dalam kedua model yang digunakan adalah sama. Pada kelas yang diterapkan model pembelajaran Learning together dikombinasikan dengan Drill and Practice maupun Learning Cycle $5 E$ siswa dituntut untuk melaksanakan praktikum dan menyusun laporan secara individu. Sehingga setiap siswa pada kedua kelas yang diterapkan dengan model pembelajaran yang berbeda tersebut akan memperoleh prestasi belajar aspek keterampilan dengan hasil tidak jauh berbeda.

Tabel 5. Hasil Uji Hipotesis Prestasi Belajar

\begin{tabular}{|c|c|c|c|c|c|}
\hline Hasil Uji Hipotesis & Sumber & $\alpha$ & Sig. & Keputusan & Kesimpulan \\
\hline \multirow{3}{*}{$\begin{array}{l}\text { Aspek Pengetahuan } \\
\text { (Dua Jalan Sel tak } \\
\text { Sama) }\end{array}$} & Model LT \& DP dan LC 5E & 0,05 & 0,039 & $\mathrm{H}_{0}$ ditolak & Terdapat Perbedaan \\
\hline & Keterampilan Proses & 0,05 & 0,015 & $\mathrm{H}_{0}$ ditolak & Terdapat Perbedaan \\
\hline & $\begin{array}{l}\text { Model*Keterampilan Proses } \\
\text { (Interaksi) }\end{array}$ & 0,05 & 0,260 & $\mathrm{H}_{0}$ diterima & Tidak ada interaksi \\
\hline \multirow{3}{*}{$\begin{array}{l}\text { Aspek Keterampilan } \\
\text { (Dua Jalan Sel tak } \\
\text { Sama) }\end{array}$} & Model LT \& DP dan LC 5E & 0,05 & 0,992 & $\mathrm{H}_{0}$ diterima & $\begin{array}{l}\text { Tidak Terdapat } \\
\text { Perbedaan }\end{array}$ \\
\hline & Keterampilan Proses & 0,05 & 0,001 & $\mathrm{H}_{0}$ ditolak & Terdapat Perbedaan \\
\hline & $\begin{array}{l}\text { Model*Keterampilan Proses } \\
\text { (Interaksi) }\end{array}$ & 0,05 & 0,032 & $\mathrm{H}_{0}$ ditolak & Terdapat interaksi \\
\hline \multirow{3}{*}{$\begin{array}{l}\text { Aspek Sikap } \\
\text { (Kruskal Wallis) }\end{array}$} & Model LT \& DP dan LC 5E & 0,05 & 0,033 & $\mathrm{H}_{0}$ ditolak & \multirow{3}{*}{$\begin{array}{l}\text { Terdapat Perbedaan } \\
\text { Terdapat Perbedaan } \\
\text { Tidak terdapat } \\
\text { interaksi }\end{array}$} \\
\hline & Keterampilan Proses & 0,05 & 0,038 & $\mathrm{H}_{0}$ ditolak & \\
\hline & $\begin{array}{l}\text { Model*Keterampilan Proses } \\
\text { (Interaksi) }\end{array}$ & 0,05 & 0,116 & $\mathrm{H}_{0}$ diterima & \\
\hline
\end{tabular}

Tabel 6. Rataan Nilai Prestasi Belajar

\begin{tabular}{llccc}
\hline \multirow{2}{*}{ Prestasi Belajar } & \multicolumn{1}{c}{ Model Pembelajaran } & \multicolumn{2}{c}{ Keterampilan Proses } & \multirow{2}{*}{ Total } \\
\cline { 3 - 4 } Aspek Pengetahuan & Model LT \& DP & 80,57 & Rendah & \\
& Model LC 5E & 88,00 & 77,45 & 79,50 \\
& Total & 84,10 & 79,69 & 84,62 \\
\multirow{3}{*}{ Aspek Sikap } & Model LT \& DP & 3,30 & 3,67 & 82,06 \\
& Model LC 5E & 3,69 & 3,41 & 3,28 \\
\multirow{5}{*}{ Aspek Keterampilan } & Total & 3,56 & 3,21 & 3,56 \\
& Model LT \& DP & 84,68 & 83,08 & 84,03 \\
& Model LC 5E & 87,20 & 80,58 & 84,72 \\
& Total & 85,97 & 81,88 & 84,38 \\
\hline
\end{tabular}

Keterangan:

1) Model LT \& DP: Model Learning Together dan Drill and Practice

2) Model Learning Cycle 5E: Model Learning Cycle 5E 
Hasil pengujian hipotesis prestasi belajar aspek sikap siswa dari kedua model pembelajaran yang diterapkan menunjukkan bahwa signifikansi uji yang diperoleh adalah 0,033. Hal ini berarti bahwa terdapat perbedaan prestasi belajar pada penggunaan model pembelajaran Learning Cycle 5E dan Learning Together dikombinasi dengan Drill and Practice. Besarnya rataan nilai prestasi belajar aspek sikap siswa yang diterapkan model pembelajaran Learning Cycle $5 E$ lebih besar dari rataan nilai prestasi belajar aspek sikap siswa yang diterapkan model pembelajaran Learning Together dikombinasi dengan Drill and Practice.

Dalam pelaksanaan model pembelajaran Learning Cycle $5 E$ siswa tidak hanya mendengarkan penjelasan materi dari guru, tetapi juga berperan aktif untuk mengeksplorasi, menjelaskan dan mengevaluasi pemahamannya mengenai materi yang dipelajari.Selain itu penerapan model pembelajaran Learning Together dikombinasi dengan Drill and Practice siswa dituntut untuk saling kerjasama dan bertanggung jawab dengan anggota kelompoknya saat diskusi berlangsung. Akan tetapi, dalam penerapan model ini, tanggungjawab individu siswa rendah, hal ini karena satu orang siswa akan merasa lebih baik melakukan seluruh pekerjaan kelompoknya, tanpa melibatkan anggota kelompok yang lain. Sehingga siswa yang belum memahami materi dengan baik, cenderung akan malas untuk memahami materi yang sedang dipelajari. Karena tugas kelompok yang diberikan sudah dikerjakan oleh anggota kelompok lainnya yang sudah memahami materi yang sedang dipelajari.Selain itu, metode Drill and Practice ini dapat menghambat bakat dan inisiatif murid, karena murid lebih banyak dibawa kepada konformitas dan diarahkan kepada uniformitas.

\section{Hipotesis Kedua}

Pengujian hipotesis kedua adalah untuk mengetahui perbedaan prestasi belajar siswa yang memiliki keterampilan proses tinggi dan keterampilan proses rendah. Hasil uji hipotesis untuk aspek pengetahuan ditinjau dari keterampilan proses siwa menunjukkan bahwa signifikansi yang diperoleh adalah 0,015. Hal ini berarti terdapat perbedaan prestasi belajar antara siswa yang memiliki keterampilan proses tinggi dengan siswa yang memiliki keterampilan proses rendah.

Terdapatnya perbedaan prestasi belajar siswa ini dikarenakan keterampilan proses diperlukan untuk menggunakan dan memahami sains
(Mustakini, 2005). Siswa yang mempunyai kemampuan akademik berbeda kemudian dikondisikan dalam pembelajaran yang sama, maka akan memperoleh hasil belajar yang berbeda pula sesuai dengan tingkat kemampuannya (Sanjaya, 2008). Dalam hal ini, keterampilan proses termasuk ke dalam salah satu kemampuan akademik siswa. Oleh karena itu, siswa yang memiliki keterampilan proses yang berbeda cenderung akan memperoleh hasil belajar yang berbeda.

Hasil uji hipotesis untuk aspek keterampilan ditinjau dari keterampilan proses siwa menunjukkan bahwa signifikansi yang diperoleh adalah 0,001 . Hal ini berarti terdapat perbedaan prestasi belajar antara siswa yang memiliki keterampilan proses tinggi dengan siswa yang memiliki keterampilan proses rendah. Perbedaan yang timbul ini disebabkan siswa yang memiliki keterampilan proses tinggi cenderung akan lebih mudah melaksanakan praktikum dan mampu mendapatkan pemahaman yang lebih baik terhadap materi yang sedang dipelajari.

Hasil uji hipotesis untuk aspek sikap ditinjau dari keterampilan proses siwa menunjukkan bahwa signifikansi yang diperoleh adalah 0,038 . Hal tersebut menunjukkan bahwa terdapat perbedaan prestasi belajar antara siswa yang memiliki keterampilan proses tinggi dengan siswa yang memiliki keterampilan proses rendah.

Aspek sikap dan keterampilan proses yang diamati saling berpengaruh secara positif. Selain itu, Popham (1995) juga menjelaskan bahawa aspek sikap seorang siswa menentukan keberhasilan proses belajarnya (Popham, 1999). Seorang peserta didik yang tidak memiliki minat terhadap mata pelajaran tertentu, maka akan kesulitan untuk mencapai ketuntasan proses belajar secara maksimal. Sedangkan peserta didik yang memiliki minat terhadap mata pelajaran, akan sangat membantu untuk mencapai ketuntasan pembelajaran secara maksimal. Dengan demikian, akan terjadi perbedaan prestasi belajar aspek sikap pada siswa yang memiliki tingkat keterampilan proses tinggi dan tingkat keterampilan proses rendah.

Berdasarkan data pada Tabel 6 dapat diketahui bahwa besarnya rataan nilai siswa yang memiliki keterampilan proses tinggi cenderung memiliki nilai prestasi belajar yang lebih tinggi dibandingkan dengan siswa yang memiliki keterampilan proses rendah. Hal ini dapat disebabkan karena siswa yang memiliki keterampilan proses tinggi akan cenderung lebih 
mudah mengikuti proses pembelajaran dengan baik. Sehingga indikator penilaian dari aspek pengetahuan, sikap maupun keterampilan akan mampu tercapai dengan tinggi pula. Oleh karena itu, siswa tersebut akan mendapatkan prestasi belajar yang lebih tinggi dibandingkan siswa yang memiliki keterampilan proses rendah.

\section{Hipotesis Ketiga}

Pengujian hipotesis ketiga adalah untuk mengetahui interaksi antara model pembelajaran Learning Cycle $5 E$ dan Learning Together dikombinasi dengan Drill and Practice dengan keterampilan proses terhadap prestasi belajar siswa pada materi pokok hidrolisis garam.

Hasil pengujian hipotesis untuk aspek pengetahuan menunjukkan bahwa signifikansi uji yang diperoleh adalah 0,260 . Hal ini berarti bahwa tidak terdapat interaksi antara model pembelajaran Learning Cycle $5 E$ dan Learning Together dikombinasi dengan Drill and Practice dengan keterampilan proses siswa terhadap prestasi belajar aspek pengetahuan siswa pada materi pokok hidrolisis garam.

Tidak terdapatnya interaksi ini dapat dilihat dari siswa yang memiliki keterampilan proses tinggi dan rendah memiliki pengaruh yang sama pada kelas yang diterapkan model pembelajaran Learning Cycle $5 E$ maupun Learning Together dikombinasi dengan Drill and Pracice pada prestasi belajar aspek pengetahuan. Hal ini dapat dimungkinkan karena siswa tidak terbiasa dengan penerapan model pembelajaran yang diterapkan, sehingga dalam pelaksanaannya kurang maksimal. Hal tersebut menyebabkan indikator-indikator keterampilan proses siswa yang dinilai tidak dapat teramati dengan baik. Selain itu, dapat juga disebabkan oleh faktor-faktor yang bukan menjadi faktor yang mempengaruhi prestasi belajar siswa dalam penelitian. Sehingga keterampilan proses dan model pembelajaran yang diterapkan bukan satu-satunya faktor internal dan eksternal yang mempengaruhi pencapaian prestasi belajar aspek pengetahuan yang diperoleh siswa. Hal ini sejalan dengan pendapat Dwijono, Sunarno, \& Sugiyarto (2013, p. 130) yang menyatakan bahwa tidak terdapatnya interaksi terhadap aspek pengetahuan siswa dapat disebabkan oleh faktor-faktor yang bukan menjadi faktor yang mempengaruhi prestasi belajar siswa dalam penelitian Dwijono, Sunarno, \& Sugiyarto (2013), dalam hal ini adalah model pembelajaran dan keterampilan proses.
Untuk faktor internal lain yang mempengaruhi prestasi belajar aspek pengetahuan yang dicapai siswa yaitu kecerdasan yang dimiliki oleh setiap individu siswa. Sebagaimana yang dikemukakan oleh Maulidah dan Santoso (2012) yaitu bahwa kecerdasan yang dapat mempengaruhi siswa terdiri dari tujuh kecakapan primer yaitu kemampuan menggunakan bahasa, kefasihan kata-kata, kecakapan menghitung, kemampuan orientasi ruang, kemampuan memori, kemampuan mengamati dengan cermat dan tepat, serta kemampuan berpikir logis. Sehingga keterampilan proses bukan satu-satunya faktor internal siswa yang mempengaruhi pencapaian prestasi belajar aspek pengetahuan yang diperoleh siswa pada materi hidrolisis garam. Sedangkan untuk faktor eksternal yang mempengaruhi prestasi belajar aspek pengetahuan yang dicapai siswa selain model pembelajaran yang diterapkan adalah suasana pembelajaran yang berlangsung dan waktu pembelajaran serta hal-hal lain yang tidak dapat dikontrol dalam penelitian yang dilakukan.

Besarnya rataan nilai prestasi belajar aspek pengetahuan yang diterapkan model pembelajaran Learning Together yang dikombinasikan dengan Drill and Practice pada siswa kategori keterampilan proses tinggi adalah 80,57 dan siswa dengan kategori keterampilan proses rendah 77,45. Sedangkan rata-rata nilai prestasi belajar aspek pengetahuan yang diajarkan model pembelajaran Learning Cycle $5 E$ pada siswa dengan kategori keterampilan proses tinggi adalah 88,00 dan siswa dengan kategori keterampilan proses rendah adalah 79,69. Data tersebut menunjukkan bahwa siswa yang memiliki keterampilan proses tinggi maupun rendah yang diterapkan model pembelajaran Learning Cycle $5 E$ memiliki prestasi belajar aspek pengetahuan lebih baik dibandingkan dengan siswa yang diterapkan model pembelajaran Learning Together yang dikombinasikan dengan Drill and Practice.

Hasil pengujian hipotesis prestasi belajar aspek keterampilan siswa menunjukkan bahwa signifikansi uji yang diperoleh adalah 0,032 . Hal ini berarti bahwa terdapat interaksi antara model pembelajaran Learning Cycle 5E dan Learning Together dikombinasi dengan Drill and Practice dengan keterampilan proses siswa terhadap prestasi belajar aspek keterampilan siswa pada materi pokok hidrolisis garam.

Terdapatnya interaksi ini dikarenakan siswa dengan keterampilan proses tinggi dan rendah memberikan pengaruh yang berbeda 
pada kelas yang diterapkan model pembelajaran Learning Cycle $5 E$ dan Learning Together dikombinasi dengan Drill and Practice pada prestasi belajar aspek keterampilan. Adanya interaksi menunjukkan bahwa terdapat pengaruh bersama (join effect) antara model pembelajaran yang diterapkan dengan keterampilan proses siswa terhadap prestasi belajar aspek keterampilan siswa pada materi pokok hidrolisis garam. Untuk mengetahui kombinasi model dan keterampilan proses mana yang lebih berpengaruh secara signifikan, dilakukan uji lanjut anava dengan metode uji Scheffe.

Hasil uji Scheffe diperoleh nilai Sig. > 0,050 untuk semua jenis kombinasi modelketerampilan proses. Sehingga, dapat disimpulkan bahwa adanya interaksi antara model pembelajaran yang diterapkan dan keterampilan proses tidak memberikan pengaruh yang signifikan terhadap prestasi belajar aspek keterampilan siswa pada materi Hidrolisis Garam.

Sementara itu, berdasarkan rataan nilai prestasi belajar yang diperoleh siswa pada Tabel 6, maka adanya interaksi ini menunjukkan bahwa siswa yang memiliki keterampilan proses tinggi akan lebih cocok menggunakan model pembelajaran Learning Cycle 5E, sedangkan siswa yang memiliki keterampilan proses rendah akan cocok menggunakan model pembelajaran Learning Together yang dikombinasikan dengan Drill and Practice.

Hasil pengujian hipotesis melalui Uji $K$ Independent Samples terhadap nilai prestasi belajar aspek sikap menunjukkan bahwa signifikansi uji yang diperoleh adalah sebesar 0,116. Hal ini berarti bahwa tidak terdapat interaksi antara model pembelajaran Learning Cycle $5 E$ dan Learning Together yang dikombinasikan dengan Drill and Practice dengan keterampilan proses siswa terhadap prestasi belajar aspek sikap siswa pada materi pokok hidrolisis garam.

Tidak terdapatnya interaksi ini dimungkinkan karena pencapaian prestasi belajar aspek sikap siswa relatif sama, meskipun diterapkan model pembelajaran yang berbeda yaitu Learning Cycle $5 E$ dan Learning Together dikombinasi dengan Drill and Practice.

\section{SIMPULAN}

Terdapat perbedaan prestasi belajar siswa aspek pengetahuan dan aspek sikap yang menggunakan model pembelajaran Learning Cycle 5E dan Learning Together yang dikombinasikan dengan Drill and Practice, dengan siswa yang diberikan penerapan model pembelajaran
Learning Cycle 5E akan memiliki prestasi belajar yang lebih baik dibandingkan siswa yang diberikan penerapan model pembelajaran Learning Together yang dikombinasikan dengan Drill and Practice, tetapi tidak terdapat perbedaan terhadap aspek keterampilan siswa.

Terdapat perbedaan prestasi belajar pada aspek pengetahuan, aspek sikap dan aspek keterampilan pada siswa yang memiliki keterampilan proses tinggi dan keterampilan proses rendah, dengan siswa yang memiliki keterampilan proses tinggi akan memiliki prestasi belajar yang lebih baik dibandingkan siswa yang memiliki keterampilan proses rendah

Terdapat interaksi antara model pembelajaran Learning Cycle 5E (Kelas Eksperimen I) dan Learning Together yang dikombinasikan dengan Drill and Practice (Kelas Eksperimen II) dengan keterampilan proses siswa terhadap prestasi belajar aspek keterampilan siswa, tetapi tidak terdapat interaksi terhadap aspek pengetahuan dan aspek sikap siswa. Interaksi ini menunjukkan bahwa siswa yang memiliki keterampilan proses tinggi cenderung akan lebih cocok menggunakan model pembelajaran Learning Cycle 5E, sedangkan siswa yang memiliki keterampilan proses rendah akan lebih cocok menggunakan model pembelajaran Learning Together yang dikombinasikan dengan Drill and Practice.

Berdasarkan penelitian yang telah dilakukan, peneliti memberikan saran sebagai berikut: (1) Dalam penerapan model pembelajaran Learning Cycle $5 E$ diperlukan persiapan yang lebih matang agar pelaksanaan pembelajaran dapat sesuai dengan sintaks yang telah ditetapkan. (2) Perlu dilakukan penelitian lebih lanjut terkait penerapan model pembelajaran Learning Together yang dikombinasikan dengan Drill and Practice dan atau Learning cycle $5 E$ pada materi pokok hidolisis garam dengan mempertimbangkan variabel moderator selain keterampilan proses terhadap prestasi belajar siswa. (3) Untuk penelitian yang berkaitan dengan keterampilan proses, perlu dilakukan percobaan menggunakan bentuk instrumen selain pilihan ganda dan observasi.

\section{DAFTAR PUSTAKA}

Dimyati, \& Mudjiono. (2002). Belajar dan pembelajaran. Jakarta: Rineka Cipta.

Dwijono, D., Sunarno, W., \& Sugiyarto, S. (2013). Pembelajaran biologi dengan pendekatan starter eksperimen (PSE) melalui inkuiri terbimbing dan inkuiri 


\section{Jurnal Inovasi Pendidikan IPA, 4 (1), 2018 - 113}

Mita Fujiyanti, Endang Susilowati, Sulistyo Saputro

bebas termodifikasi ditinjau dari keterampilan proses sains dan kreativitas siswa. Inkuiri, 2(02). Retrieved from http://jurnal.fkip.uns.ac.id/index.php/inkui ri/article/view/3792

Gregory, R. J. (2004). Psychological testing: History, principles, and applications. Allyn \& Bacon.

Huda, M. (2012). Cooperative Learning metode, teknik, struktur dan model penerapan. Yogyakarta: Pustaka Pelajar.

Kuswaya, W., \& Wardani, I. (2008). Penelitian tindakan kelas. Jakarta: Universitas Terbuka.

McDonough, S. K. (2001). Way behond drill and practice: Foreign language lab activities in support of constructivist learning. International Journal of Instructional Media, 28(1), 75.

Mustakini, J. H. (2005). Model kesuksesan sistem teknologi informasi. Yogyakarta:
Andi Offset.

Popham, W. J. (1999). Classroom assessment: What teachers need to know. Allyn and Bacon.

Presiden Republik Indonesia. Undang-Undang Republik Indonesia nomor 20 tahun 2003 tentang sistem pendidikan nasional, Pub. L. No. 20, Undang-Undang Republik Indonesia 26 (2003). Indonesia.

Sagala, S. (2010). Konsep dan makna pembelajaran. Bandung: Alfabeta.

Sanjaya, W. (2008). Strategi pembelajaran berorientasi standar proses pendidikan. Jakarta: Prenada Media. https://doi.org/2008

Shoimin, A. (2014). 68 model pembelajaran inovatif dalam Kurikulum 2013. Yogyakarta: Ar-Ruzz Media.

Slavin, R. E. (2015). Cooperative learning: Theory, research, and practice. Allyn and Bacon. 